\title{
The role of stimulating employees' creativity and idea generation in encouraging innovation behaviour in Irish firms
}

Research Article

\author{
Justin Doran and Geraldine Ryan* \\ School of Economics, University College Cork, Ireland
}

\begin{abstract}
This paper analyses the impact of stimulating staff creativity and idea generation on the likelihood of innovation. Using data for over 3,000 firms, obtained from the Irish Community Innovation Survey 2008-2010, we examine the impact of six creativity generating stimuli on product, process, organisational and marketing innovation. Our results indicate that the stimuli impact the four forms of innovation in different ways. For instance, brainstorming and multidisciplinary teams are found to stimulate all forms of innovation, rotation of employees is found to stimulate organisational innovation, while financial and non-financial incentives are found to have no effect on any form of innovation. We also find that the co-introduction of two or more stimuli increases the likelihood of innovation more than implementing stimuli in isolation. These results have important implications for management decisions in that they suggest that firms should target their creative efforts towards specific innovation outcomes.
\end{abstract}

Keywords: componential theory of creativity; creativity; idea generation; innovation; Ireland

(C) De Gruyter Open Sp. z 0.0.

\section{INTRODUCTION}

Today a firm's growth and survival depend on its ability to innovate (Hossain, 2013; Varis and Littunen, 2010). Firms that innovate to improve their processes, differentiate their products and/or transform their structure have been shown to regularly outperform their competitors (Tidd, 2001). At the heart of all organisational innovation lies creative ideas and it is individual employees, who alone or in groups, generate, promote, discuss, modify and realize these ideas (Cirella and Shani, 2012; Scott and Bruce, 1994). Creativity has been widely accepted as a key ingredient of innovation (Amabile, 1996; Çokpekin and Knudsen, 2012; Mumford, 2000; Shalley et al., 2004) thus, organisations are dependent on the creativity, and the innovative engagement of their employees. In many firms, action is taken to stimulate such creativity and hence innovation (Martins and Terblanche, 2003) as firm owners and managers search for effective, efficient and competitive ways to give their firms the competitive edge. In this paper, we examine whether idea generation and creativity stimuli foster innovation.

To date, a lot of attention has been paid to the role of research and development (Cohen et al., 1987; Doran et al., 2013) and networking (Boschma, 2005; Doran et al., 2012b; Freel, 2003) in the innovation performance of firms. While a number of qualitative studies and case studies have been conducted on the role less tangible factors such as brainstorming and multidisciplinary teams play in a firm's innovation performance, there has been relatively little quantitative analysis. Drawing on insights from the Componential Theory of Creativity (Amabile, 1988, 1996; Amabile and Mueller, 2008), this paper addresses this gap in the literature, by providing insights into the role these less tangible forms of creativity and idea generation stimuli have on the innovation performance of firms. The results from this study will help managers understand which methods of generating ideas and creativity to invest in.

The central question addressed by this paper is whether idea generation and creativity stimuli, other than networking or research and development, result in innovation. This analysis is facilitated through the use of the Irish Community Innovation Survey (CIS) which contained a special module in 2008-2010 on the methods firms 
use to stimulate new ideas or creativity among their staff. The factors considered are (i) brainstorming sessions, (ii) multidisciplinary work teams, (iii) job rotation of staff, (iv) financial incentives, (v) non-financial incentives and (vi) training employees on how to develop new ideas.

We consider four types of innovation: product, process, organisational and marketing. The Oslo Manual notes that these forms of innovation are a mixture of technical and non-technical innovation which may have different determinants (OECD, 2005). Indeed in the context of R\&D, Doran et al. (2013) note that different forms of R\&D have diverse impacts on the likelihood of performing different forms of innovation. Therefore, it is possible that our idea generation and creativity stimuli may have a differentiated impact on innovation types. We assess the importance of our stimuli on as wide a spectrum of innovation types as our data facilitate to ascertain whether there are any commonalities or substantive differences in their effectiveness. The remainder of this paper is structured as follows. Section 2 presents a review of the literature. The data and methods are presented in Section 3. The results are set out in Section 4, while Section 5 discusses these results. Section 6 concludes our study.

\section{LITERATURE REVIEW}

Innovation is the key to maintaining competitiveness in the global market. The capability of a firm to develop new goods and services, to transform its structure into a more efficient one and to make its marketing more competitive determines its success. Since idea generation and creativity are fundamental to innovation, firm owners and managers frequently encourage, stimulate, fund and reward such activities (Hansen and Birkinshaw, 2007; OECD, 2005; Roper et al., 2008). We begin this section by examining what is meant by idea generation and creativity stimuli, and how these concepts are linked to innovation. Following this we examine the Componential Theory of Creativity (Amabile, 1988, 1996; Amabile and Mueller, 2008) and use it to identify stimuli that may enhance organisational creativity.

\section{Linking idea generation, creativity and innovation}

Since the concepts of idea generation, creativity and innovation are used interchangeably in the literature (Ford, 1996; Shalley et al., 2004), it is important to analyse them in the context of this research. An idea is classified as being new if it is new to the firm. New ideas can either be novel ideas or they can be copied from other places. The term creativity, on the other hand, refers only to useful, novel and relevant ideas (Amabile, 1996; Heinze, 2013; Rank et al., 2004). Mumford (2012) defines creativity as the 'production of high quality, original and elegant solutions to problems'. For an idea to be considered as creative, it must be useful, relevant and novel at the same time. Beheshtifar and Kamani-Fard (2013) argue that an individual's level of creativity is driven by their expertise, their creative-thinking skills and their level of motivation. Amabile (2013) argues that managers can stimulate and facilitate organisational creativity, where organisational creativity is defined by Woodman et al. (1993) as the 'creation of a valuable, useful new product, service, idea, procedure or process by individuals working together in a complex social system'. Cirella and Shani (2012) argue that creativity within organisations happens when people work together to trigger ideas through dialogue, debate and conflict. Similarly, Baer et al. (2010) argue that organisations rely on both team-based structures and internal competition between these teams to elicit creativity.

Innovation is the successful application of creativity and as a result creatively is said to ignite innovation (Amabile, 1996; Çokpekin and Knudsen, 2012; Mumford, 2000; Shalley et al., 2004). Innovation is not the same as creativity (Amabile, 1996; Lewis and Wright, 2012). When a company decides to introduce a new good or service, it creates lots of ideas, and then picks the best of these for development (Girotra et al., 2010). In other words, innovation involves the crafting of creative ideas into new products, processes or services (Mumford, 2012; Nyström, 1979). Given the importance of idea generation and creatively for innovation, extensive research has studied factors stimulating employee creativity (Beheshtifar and Kamani-Fard, 2013; Ford, 1996; Woodman et al., 1993) and has acknowledged the importance of a supportive work environment (Amabile, 1996). Despite this Çokpekin and Knudsen (2012) and Puccio and Cabra (2010) argue that there is still little evidence to show whether boosting creativity results in innovation, and Ettlie and Reza (1992) question whether different types of stimuli are required to motivate the different types of innovation. In this paper, we address both these questions.

\section{Stimulating idea creation and creativity}

Since new ideas and creativity are prerequisites for innovation, and innovation is essential for survival and growth in the modern economy, it is important that organisations manage and develop these attributes. One primary model 
of creativity is the Componential Model of Organisational Creativity (developed by Amabile (1988) and updated by Amabile (1996) and Amabile and Mueller (2008)). This model argues that creativity arises through the coming together of four elements: three relate to the individual - knowledge (all the relevant understanding an individual brings to bear on a creative effort), creative thinking (how people approach problems) and motivation (the passion and interest the individual has for their work), and one relates to the external environment in which the individual works. The model identifies a number of ways creativity can be stimulated by adapting these four elements. In this section, we begin by briefly examining knowledge, creative thinking and motivation before turning to how the collective introduction of these elements can create a supportive and stimulating environment which fosters creativity and innovation.

\section{Knowledge}

Gardner (1993) argues that two types of knowledge are required for creativity. Firstly, employees need to build their technical expertise over time. This knowledge then acts as a solid foundation from which creativity can emerge. Without this knowledge base, Simonton (1980) suggests that individuals cannot be creative. Secondly, employees need to be able to recognise opportunities and combine previously disparate elements in new ways. Johansson (2004) argues that a balance is needed between these elements and Adams (2006) proposes that one way to achieve this balance is by building multi-disciplinary teams. This mirrors the general innovation literature, which suggests that team processes and behaviours such as reflexivity and knowledge sharing are important predictors of innovation (DeDreu, 2002).

Knowledge is a unique asset to a firm; in the right hands, it can create immense value, however, people can leave the business at any moment in time, taking all their knowledge with them. It is not easy to create or share knowledge. While it is the ultimate economic renewable, and its value comes from sharing it with others, it is very difficult to encourage and facilitate this sharing. Knowledge sharing is an important dimension of innovation, particularly the sharing of new, diverse knowledge. Nahapiet and Ghoshal (1998) model learning and argue that it takes place through the combination and exchange of knowledge. Knowledge can be combined by merging knowledge that was previously unconnected or by finding novel ways of blending pre-existing knowledge. This process is often dependent on the exchange of information, especially where resources are held by different parties. Moran and Ghoshal (1996) contend that for knowledge sharing to be effective, there must be an opportunity for employees to share information. This can be done through the structure of the firm where a flat structure with autonomy and work teams has been found to promote innovation, while specialisation, formalisation, standardisation and centralisation inhibit innovation (Martins and Terblanche, 2003).

When innovation is mandated professionals such as researchers, engineers, designers and programmers often collaborate on assigned or original projects (Sundstrom et al., 1990). Mohrman et al. (1995: 6) define a team as 'a group of individuals who work together to produce products or deliver services for which they are mutually accountable'. They go on to propose that 'team members share goals and are mutually held accountable for meeting them, they are interdependent in their accomplishment, and they affect the results through their interactions with one another'. Groups composed of people with differing professional backgrounds, knowledge, skills and abilities will be more innovative than those whose members are similar, because they bring differing perspectives on issues to the group (Paulus, 2000; West, 2002). Their divergence of views can create multiple perspectives, which if managed correctly can lead to more innovative actions (Paulus, 2000). The ability to rotate to different projects and positions within a firm increases the level of flexibility within a firm and it is values like flexibility, freedom and cooperative teamwork which promote creativity and innovation (Martins and Terblanche, 2003). On this basis we hypothesise that:

H1: Knowledge generation stimuli, such as work teams and job rotation, are positively related to innovation output.

\section{Creative thinking}

Since creativity involves the production of high-quality, original, and elegant solutions to complex, novel, ill-defined or poorly structured problems (Mumford and Gustafson, 1988), it is essential that individuals are able to combine existing elements of knowledge or understanding in new ways. This calls for creative thinking. Mumford et al. (2012) argue that creative thinking involves multiple, complex processing operations, and the execution of these processes depends on the knowledge available to the individual at the time and the procedures he/she uses 
when executing the processes. They argue that the creative-thinking process begins with problem definition. This is followed by information gathering, information organisation, conceptual combination, idea generation, idea evaluation, implementation planning and solution monitoring. These processes operate in a dynamic fashion and failure to adequately complete any one stage will lead individuals to step-back to early processing activities. Adams (2006) argues that the creative mind can be enhanced by environments or efforts that encourage individuals to generate new variations and new combinations of ideas.

Brainstorming is one of the most popular techniques used to induce creativity (Adams, 2006). Its purpose is to generate a limited number of good ideas which can be developed further with a view to implementing them (Nijstad and De Dreu, 2002). Johansson (2004), amongst others, argues that group brainstorming can be particularly effective when individuals are allowed 15-20 minutes to think individually and write their ideas on an anonymous piece of paper which is then handed to a facilitator. All ideas can then be discussed openly with a view to considering whether each one could be feasible rather than seeking to criticise or find the reasons why it wouldn't work. Rietzschel et al. (2006) and West (2002) claim that this type of group brainstorming can outperform individuals working alone, particularly on intellective tasks whilst Paulus (2000) reports that sharing ideas with others in a team can increase the chances of producing novel ideas. We hypothesise that

\section{H2: Creative thinking stimuli, such as brainstorming, are positively related to innovation output.}

While creative thinking depends a lot on an individual's characteristics (e.g. independence, self-discipline, risktaking attitude, willingness to deal with failure), Amabile (1996) argues that these skills can be increased with education and training. The acquisition of information about the job enables employees to broaden and enrich their knowledge of the job task, task problems and the job context. Weisberg (1999) presents theoretical and empirical evidence which suggests that work-based learning strategies promote knowledge acquisition and that knowledge acquired in this way boosts the potential to create and generate new and useful ideas. Since the innovation process is knowledge intensive and since employees may need to acquire new knowledge to participate in the development and implementation of ideas, we anticipate that job-specific-training is positively related to innovation output. Using this theoretical and empirical evidence we hypothesise:

\section{H3: Creative thinking stimuli, such as job-specific training, are positively related to innovation output.}

\section{Motivation}

The third element in the Componential Theory of Creativity is motivation. Mitchell (1982) defines motivation as 'the psychological processes that cause the arousal, direction and persistence of behaviour'. Ames (1992) argues that motivation is the reason individuals behave in a particular manner in a certain situation. Motivation exists as part of one's goal structures, one's beliefs about what is important, and it determines whether or not one will engage in any given pursuit. Deci (1975) separates motivation into extrinsic and intrinsic motivation. While extrinsically motivated people do the work because of some threat (e.g. evaluation, surveillance, competition with peers) or because there is some promise of reward (e.g. money, promotion), intrinsically motivated people do the work because they find it interesting, involving, exciting, satisfying or personally challenging. Lindenberg (2001) further sub-divides intrinsic motivation into normative and hedonic motivation. The former group act because they want to comply with personal, social or organisational norms, while the latter group act because they find the task challenging, exciting and enjoyable. Amabile (1996) argues that people are more creative when they are hedonically intrinsically motivated as they are more likely to explore various pathways and alternatives.

Incentives are commonly used in business to motivate employees and to align their wants with the needs of the employer (Laffont and Martimort, 2002). The purpose of an incentive is to provide the decision maker with a reason to follow a particular course of action. Brynjolfsson and Mendelson (1997) argue that the best way for employers to induce the optimal level of effort from their employees is to base their salary directly on the effort they exert. However, paying according to effort requires that the employer can monitor the employee perfectly and cheaply. In many cases, it is not possible to do this and therefore carefully designed incentive mechanisms are needed. The behavioural literature on compensation systems warns that using incentives often leads to unintentional and dysfunctional consequences. Asymmetric information and unintended consequences can make incentives much more complex than the people offering them originally expected and can lead either to unexpected windfalls or to disasters. The problem with incentive contracts is not that they don't work but that 
they work too well. Agents do exactly as the incentive desires. For example, contracts that promote quantity often result in poor quality products or if bonuses are more dependent on timely project completion than on discovered failures, the employee may over invest in expedience at the expense of quality (Wash and MacKie-Mason, 2006).

Intrinsically motivated people and extrinsically motivated people need to be incentivised in different ways. While hedonically intrinsically motivated employees may be more likely to be creative, they can be demotivated by certain types of extrinsic rewards. Amabile (1996) identifies two types of extrinsic motivators: non-synergistic motivators and synergistic motivators. The former are controlling and they are likely to have negative impacts on creativity. For example, when monetary rewards are given for meeting specific targets, then employees only do what is necessary to meet that target. Synergistic motivators, on the other hand, support creativity and can be informational or enabling motivators. These motivators include things like frequent constructive feedback on the work, reward and recognition for creative ideas and clearly defined overall project goals. This idea is supported by recent survey findings which show that non-financial incentives are more effective and valued by employees than financial incentives. A survey, conducted by MacKinsey Quarterly, found that praise is the best incentive as it makes employees feel like the firm appreciates them (Dewhurst et al., 2009). Other incentives valued by employees are leadership attention (for example, one-on-one conversations), and a chance to lead projects or task forces. We hypothesise that

H4: Non-financial incentives support hedonically intrinsically motivated employees and hence increase creativity and innovation whilst financial incentives have less of a positive impact.

\section{The work environment}

The work environment is important when motivating idea generation, creativity and innovation. Mumford (2000) argues that organisations should consider multiple interventions that take into account the individual, the group, the organisation and the strategic environment when selecting interventions intended to enhance creativity. This view is supported by the Computational Model of Creativity (Amabile, 1988, 1996; Amabile and Mueller, 2008) which argues that creativity comes from the bringing together of knowledge, creative effort, creative thinking and motivation. Mauzy et al. (2003) argue that effective information flow within an organisation is critical and according to Johansson (2004) creative success is most likely to occur where widely different ideas bump into each other. Cummings and Oldham (1997) find that organisations, which provide a supportive innovation context for creativity, tend to reap greater benefits from employees who are innately creative while Deci and Ryan (1985) find that management can motivate employees' creativity. They note that support that pays attention to the employees' needs enhances curiosity and work effort while simultaneously reducing their fear of making a mistake thereby encouraging risk-taking (Madjar and Ortiz-Walters, 2008; Shin and Zhou, 2003) and facilitating creativity. Work colleagues also play a role in creating a supportive work environment. Zhou and George (2001) show that the information and skills of co-workers generates feedback, new information and the elaboration of unusual ideas thus enhancing creativity. Mauzy et al. (2003) suggest that job rotation can help create this stimulating work environment. Adams (2006) argues that less-structured and less-bureaucratic firms are more likely to facilitate such information flows as there is likely to be more focus on idea generation and sharing rather than on career progression. Amabile (2013) affirms that many techniques can be used to stimulate a creative work environment such as the creation of work teams that are collaborative, diversely skilled and idea-focused; the creation of incentives that recognise creative work; and through creating norms for actively sharing ideas across the organisation. On the other hand, political problems within the firm, excessive time pressures and harshly criticising new ideas can block creativity. We hypothesis that

H5: Supportive work environments (i.e. those introducing more than one idea generation and creativity stimuli) enhance creativity and hence result in higher innovation output.

In the next section, we specify a model which allows us to test whether work teams and job rotation by stimulating knowledge generation increase the level of innovation within firms $(\mathrm{H} 1)$, whether brainstorming and job training by stimulating creative thinking increase the level of innovation within firms ( $\mathrm{H} 2$ and $\mathrm{H} 3)$, and whether financial or nonfinancial incentives motivate employees to become more creative and hence increase the innovation within firms $(\mathrm{H} 4)$. We also test whether a combination of these stimulating factors create a more supportive work environment which facilitates greater levels of innovation (H5). 


\section{METHODOLOGY}

The data used in this paper is derived from the Irish CIS 2008-2010. This survey was conducted jointly by Forfás (Ireland's national policy advisory body) and the Central Statistics Office (CSO) in Ireland. Consistent with the OECD's Oslo manual, the survey includes a reference period, which in this case is 2008 to 2010 , for innovation inputs and outputs (OECD, 2005). The motivation for the CIS survey is to provide a comprehensive survey of the innovation performance of Irish firms. The survey is conducted as part of the European wide CIS project and is completed every 2 years (CSO, 2010).

A detailed review of the survey methodology can be found in CSO (2012). The survey was distributed to a total of 4,532 enterprises of which 3,245 responses were returned (a response rate of $72 \%$ ). The sampling frame for the CIS 2008-2010 was based on enterprise size and the sector of operation. The CSO used the Statistical Classification of Economic Activities in the European Community (NACE Rev.2) to identify specific sectors to target. Specifically, the CIS 2008-2010 includes industry (NACE 05-39) and selected services sectors (NACE 46, 49-53, 58, 61-66 and 71). To be included in the sampling frame, the firm must have 10 or more persons engaged.

The CIS examines product, process, organisational and management innovation. We summarise the measures we use for our empirical analysis in this section and provide the exact questions asked in the CIS 2008-2010 in Appendix 1. Product innovation is composed of firms which introduce new to market and new to firm innovations. Specifically, we argue that a firm has introduced a product innovation if it has introduced a new or significantly improved good or service. It does not matter whether this product was already being supplied to the market by their competitors. This definition encapsulates both new to market and new to firm innovation. New to market innovation is defined as the introduction of a new or significantly improved good or service onto your market before the firm's competitors (it may have already been available in other markets) while new to firm innovation is defined as the introduction of a new or significantly improved good or service that was already available provided by the firm's competitors. It is common in the empirical literature to combine both of these measures (Doran et al. 2012a; Doran and Ryan, 2012). Process innovation is defined as new or significantly improved methods of manufacturing or producing goods or services, new or significantly improved logistics, delivery or distribution methods for the firm's inputs, goods or services or new or significantly improved supporting activities for the firm's processes, such as maintenance systems or operations for purchasing, accounting or computing. Organisational innovation is defined as new business practices for organising procedures, new methods of organising work responsibilities and decision making or new methods of organising external relations with other firms or public institutions. Finally, marketing innovation is defined as significant changes to the aesthetic design or packaging of a good or service, new media or techniques for product promotion, new methods for product placement or sales channels or new methods of pricing goods or services.

We note in Table 1 that $32 \%$ of firms in our sample introduced product innovations, $35 \%$ introduced process innovations, $40 \%$ introduced organisational innovations and $32 \%$ introduced marketing innovations. There is some overlap among firms which introduce innovations, with some introducing all four types while others only introduce one type of innovation.

We include a number of controls in our analysis to capture firm heterogeneity in innovation performance. Summary statistics for these are also displayed in Table 1. The controls we include are firm size, ownership, external networking, R\&D activity and sector. These are standard controls in the innovation literature, see for example Roper et al. (2008) and Freel $(2000,2003)$. We can see the average firm size in our sample is 96 employees with a standard deviation of 381 . Approximately, $73 \%$ of the firms surveyed are Irish owned. As in Roper et al. (2008), we define four types of external networking. We note that backward linkages to suppliers are the most common form of networking (12\%). This is followed by forward linkages to customers $(9 \%)$ and public interaction with universities or public research institutes $(8 \%)$. The lowest level of networking is horizontal linkages to competitors and consultants (3\%). Regarding research and development activity we control for both intramural and extramural R\&D. Intramural R\&D is defined as creative work undertaken within the firm to increase the stock of knowledge for developing new and improved products and processes while extramural R\&D is defined as the same set of activities as above, but performed by other enterprises. We also include sectorial controls for broad NACE sectors. 
Table 1. Descriptive statistics of variables

\begin{tabular}{|c|c|c|}
\hline Variable & Statistics & sd \\
\hline \multicolumn{3}{|l|}{ Innovation } \\
\hline Product (\%) & 31.37 & na \\
\hline Process (\%) & 35.75 & na \\
\hline Organisational (\%) & 39.48 & na \\
\hline Marketing (\%) & 32.2 & na \\
\hline \multicolumn{3}{|l|}{ Firm specific factors } \\
\hline Irish owned (\%) & 73.37 & na \\
\hline Employment (mean) & 96.22 & 381.54 \\
\hline \multicolumn{3}{|l|}{ Networking } \\
\hline Backwards (\%) & 12 & na \\
\hline Forwards (\%) & 9 & na \\
\hline Horizontal (\%) & 3 & na \\
\hline Public (\%) & 8 & na \\
\hline \multicolumn{3}{|l|}{ R\&D } \\
\hline Intramural R\&D (mean) & $€ 2236.13$ & 11307.95 \\
\hline Extramural R\&D (mean) & $€ 530.43$ & 5419.8 \\
\hline
\end{tabular}

Source: Irish Community Innovation Survey

\section{Methods}

The empirical approach adopted by this paper is the estimation of an innovation production function, which is prevalent in the literature on the drivers of innovation in firms (Doran and O'Leary, 2011; Freel, 2003; Love and Mansury, 2007; Roper et al., 2008). We extend the standard innovation production function to include measures of creative stimuli. Our innovation production function follows the standard form and is displayed as equation (1):

$$
1 O_{i}=\alpha_{0}+S F_{i} \alpha+R \& D_{i} \beta+N_{i} X+Z_{i} \lambda+\varepsilon_{i}
$$

The dependent variable $I_{i}$ is a binary indicator of whether firm $i$ innovated. We consider four types of innovation: (i) product, (ii) process, (iii) organisational and (iv) marketing. $\alpha_{0}$ is a constant term. We include four sets of independent variables: the first set, SF, is the key set of interest and is used to test our first four hypotheses. The remaining three sets of variables (R\&D, $N$ and $Z$ ) are included as controls in the estimation.

$S F_{i}$ is a $N^{*} 6$ matrix of variables indicating the type of stimulating factors utilised by firm $i$ to produce innovation output. The six stimulating factors considered are (i) multidisciplinary or cross-functional work teams, (ii) job rotation of staff to different departments or other parts of their enterprise group, (iii) brainstorming sessions, (iv) training employees on how to develop new ideas or creativity, (v) financial incentives for employees to develop new ideas and (vi) non-financial incentives for employees to develop new ideas, such as free time, public recognition, more interesting work, etc. $\alpha$ is a $6^{*} 1$ vector of coefficients showing the impact of these factors on the likelihood of a firm innovating. These six variables are used to test hypotheses $\mathrm{H} 1$ to $\mathrm{H} 4$ specified in Section 2.

Since it is widely established in the literature that R\&D is an important driver of innovation activity (Feldman, 1999; Love and Mansury, 2007; Mansury and Love, 2008), we control for this variable in our model. $R \& D_{i}$ is an $N^{*} 2$ matrix of variables representing the R\&D effort of the firm which includes intramural and extramural R\&D performance. $\beta$ is a vector of associated coefficients. The second control is $N_{i}$, an $N^{*} 4$ matrix of binary variables which indicate whether firm $i$ engages in backwards, forwards, horizontal or public networking. Freel $(2000,2003)$ notes that external networking may assist firms in accessing knowledge pertinent to innovation. $\mathrm{X}$ is the $4 * 1$ vector 
of associated parameters. Our last control, $Z_{i}$, represents firm-specific factors that might explain heterogeneity in the innovation performance of firms. $\lambda$ is the vector of associated coefficients. $Z_{i}$ contains information on firm size, whether it is Irish owned or not and the sector in which firm $i$ operates. These have all been previously shown to have an impact on the innovative performance of firms (Cohen and Klepper, 1996; Cohen et al., 1987; Pavitt, 1984; Roper, 2001).

As noted previously we consider four distinct types of innovation. The standard practice in the literature would be the estimation of four distinct probit models (Doran and O'Leary, 2011; Roper et al., 2008). However, it is likely that individual heterogeneity not captured by the independent variables could impact on the likelihood of firms engaging in numerous forms of innovation simultaneously. This upward bias (or indeed downward bias if the firm possesses unobserved characteristics which impede innovation performance) in innovation likelihood will manifest in the error terms, $\varepsilon_{i}$, being correlated across the four regression equations. This may result in biased estimates. Therefore, in order to take account of this potential bias, we estimate a multivariate probit model, which estimates the four equations taking account of potential correlation across the error terms (Cappellari and Jenkins, 2003, 2006).

In addition to these stimuli individually driving innovation, it is possible that engaging in a variety of activities may create a more supportive work environment and hence increase the likelihood of innovation (H5). In the context of geographical proximity and networking, Storper and Venables (2004) note that engaging with an increasing variety of individuals and ideas can stimulate the creative process within firms. McCann and Simonen (2005) test this in the context of the variety of external interaction agents firms engage in. Based upon this concept of variety stimulating innovation, we hypothesise that the variety of creative processes undertaken by the firm may stimulate the innovation process within the firm. In order to test this hypothesis, we modify equation 1 in line with McCann and Simonen (2005):

$$
1 O_{i}=\alpha_{0}+N S F_{i} \alpha+R \& D_{i} \beta+N_{i} X+Z_{i} \lambda+\varepsilon_{i}
$$

Where all variables are defined as above with the exception that $N S F_{i}$ is now a $\mathrm{N}^{*} 6$ matrix of six dummy variables indicating the number of stimulation factors implemented by the firm. Where the first dummy variable takes a value of 1 if the firm engages in any one of the stimulation factors considered and 0 otherwise. The second dummy variable takes a value of 1 if the firm utilises two stimulation factors and 0 otherwise. This continues for the third, fourth and fifth dummy variables and the final dummy variable takes a value of 1 if the firm engages all forms of stimulation factors and 0 otherwise. The coefficients thus provided in $\alpha$ indicate whether increasing the variety of stimulation increases the likelihood of innovation. Again, equation (2) is estimated using a multivariate probit model.

\section{RESULTS}

The novel element of the Irish CIS 2008-2010, which facilitates this research paper, is based around whether during the three years 2008 to 2010 the firm used any methods to stimulate new ideas or creativity among their staff. Specifically six methods of stimulating innovation were identified by the Irish CIS. Firms were asked whether they used:

(i) brainstorming sessions;

(ii) multidisciplinary or cross-functional work teams;

(iii) job rotation of staff to different departments or other parts of their enterprise group;

(iv) financial incentives for employees to develop new ideas;

(v) non-financial incentives for employees to develop new ideas, such as free time, public recognition, more interesting work, etc.;

(vi) training employees on how to develop new ideas or creativity.

Firms were asked to rank whether they successfully implemented these stimulating practices, somewhat successfully implemented these practices, were unsure if these practices were successful, or, whether they did not implement these practices. For our empirical approach, we classify firms which had some success with these methods as having implemented them, while firms which did not implement them are classified as not having engaged in these practices. This results in a series of six binary variables. Descriptive statistics for each of these stimulating practices and an abbreviated name for each factor are displayed in Table 2 . We note that $47 \%$ of firms 
surveyed did not engage in any form of creativity stimulation. Just over $16 \%$ of firms engaged in only one stimulating activity and approximately $37 \%$ engaged in more than one form. Of those who introduced idea generation and creativity stimuli, $40 \%$ of firms encouraged their employees to engage in brainstorming sessions while $30 \%$ of firms employed multidisciplinary or cross-functional work teams. Slightly less prevalent was job rotation of staff to different departments or other parts of their enterprise group which was used by $19 \%$ of firms and only $15 \%$ of firms provided training to employees on how to develop new ideas or creativity. Just $10 \%$ of firms provided non-financial incentives for employees to develop new ideas and only $9 \%$ of firms provided financial incentives for employees to develop new ideas.

Table 2. Descriptive statistics of idea generation and creativity stimuli variables

\begin{tabular}{lc}
\hline Variables & $\%$ \\
\hline \hline Number of stimuli introduced & 47.38 \\
No stimuli & 16.31 \\
One stimuli & 16.12 \\
Two stimuli & 9.99 \\
Three stimuli & 5.83 \\
Four stimuli & 2.90 \\
Five stimuli & 1.48 \\
Six stimuli & \\
Type of stimuli introduced & 30.52 \\
Work teams & 19.67 \\
Job rotation & 40.29 \\
Brainstorming & 15.84 \\
Training & 8.6 \\
Financial incentives & 10.27 \\
Non-financial incentives & \\
\hline
\end{tabular}

Source: Irish Community Innovation Survey

Table 3 presents a correlation matrix of the six idea generation and creativity stimuli considered. We can see that there is a moderate to weak positive correlation among the variables. This suggests that firms which introduce one form of stimuli may be more likely to introduce other forms of encouragement. Also, while there is some correlation, it is not sufficiently high to raise problems of possible multicollinearity.

Table 3. Correlation matrix of encouragement variables (full sample)

\begin{tabular}{|c|c|c|c|c|c|c|}
\hline & $\begin{array}{c}\text { Work } \\
\text { teams }\end{array}$ & $\begin{array}{l}\text { Job } \\
\text { rotation }\end{array}$ & Brainstorming & Training & $\begin{array}{l}\text { Financial } \\
\text { incentives }\end{array}$ & $\begin{array}{l}\text { Non-financial } \\
\text { incentives }\end{array}$ \\
\hline Work teams & 1 & & & & & \\
\hline Job rotation & 0.3357 & 1 & & & & \\
\hline Brainstorming & 0.5338 & 0.3035 & 1 & & & \\
\hline Training & 0.3046 & 0.3120 & 0.3527 & 1 & & \\
\hline Financial incentives & 0.2265 & 0.1967 & 0.2479 & 0.2824 & 1 & \\
\hline Non-financial incentives & 0.3273 & 0.2773 & 0.3041 & 0.3567 & 0.3310 & 1 \\
\hline
\end{tabular}

The results of our estimation are presented in Table 4. In this table, we are only interested in the sign and the significance of the variables. What we immediately note is that there is variation in the significance of our stimulation 
variables across innovation types. This implies that different measures designed to stimulate creativity vary in their effectiveness depending on the type of innovation considered. Firstly, looking at our knowledge creating stimuli in Table 4 we note that Work Teams have a positive and significant impact on product, process, organisational and marketing innovation, whilst Job Rotation has a positive and significant impact on organisational innovation, thus providing some support for $\mathrm{H} 1$ that knowledge sharing stimuli increase the level of innovation within firms. We also find support for $\mathrm{H} 2$ that creative-thinking tools, such as Brainstorming Sessions, increase the innovation output of firms. Like Workplace Teams these are effective at stimulating all four forms of innovation. Turning to $\mathrm{H} 3$ we find that Training only has a positive and significant effect on process and organisational innovation. This indicates that this stimulus is not as effective as Brainstorming Sessions in fostering the type of creative thinking that is required to generate product or marketing innovations. We also find some support for $\mathrm{H} 4$ in that Financial Incentives have no significant effect on any of the innovation types considered. However, contrary to our hypothesis we find no evidence that non-financial incentives support hedonically intrinsically motivated employees and encourage creativity.

To examine whether the work environment impacts on innovation output (H5), we estimate equation (2). In this equation, we test whether the simultaneous use of one or more of the creativity stimuli (i.e. work teams, job rotation, brainstorming sessions, training, financial incentives, non-financial incentives) increases innovation output. More specifically, we examine whether the use of any one, two, three, four, five or all six of the stimuli result in increased innovation output. The results of this multivariate probit model are presented in Table 5 . The reference category is 0 , that is, where no stimulating factors are being used by the firm. Like above, we are only interested in the sign and the significance of the coefficients. We note that all coefficients are positive and significant indicating that the introduction of one or more stimulating factors increases the likelihood of all forms of innovation activity. Furthermore, we note that the magnitude of the coefficient trends upwards as more stimulating factors are implemented. This suggests that higher levels of engagement by firms in stimulating diverse forms of idea generation, yields greater returns for innovation activity. ${ }^{1}$ This provides support for hypothesis $\mathrm{H} 5$.

\section{DISCUSSION}

Our findings suggest that some forms of creativity prove extremely successful in the innovation process while others are less effective. In the case of brainstorming, Adams (2006) notes that this is one of the most common forms of creativity stimulation employed by firms for innovation. Rietzschel et al. (2006) note that various forms of brainstorming can be effective, to varying degrees, in the generation of ideas. Since our data does not allow us to distinguish between different types of brainstorming we cannot test the different forms of brainstorming, however, we can nonetheless state that this common form of stimuli proves extremely successful at generating innovation output. We also find that multidisciplinary work teams increase the likelihood of all forms of innovation. This is consistent with Alves et al. (2007) who argue that the idea generation process can be particularly fruitful within collaborative multidisciplinary environments. They note that multidisciplinary teams can result in increased quantity, quality and diversity of ideas when generating new knowledge for innovation. This is further supported by Martins and Terblanche (2003) who also note the importance of structure within the organisation for promoting innovation and suggest that cooperative teams and group interaction among teams is essential for the innovative process. Hansen and Birkinshaw (2007) note that cross-unit collaboration, which can combine insights and knowledge from different parts of the same company is not always easy to achieve but that there are substantial benefits when implemented correctly. This view is also supported by West (2002).

Training for creativity is found to have a positive effect on process and organisational innovation. This finding is consistent with Amabile (1996), McLean (2005) and Weisberg (1999) who suggest that elements of an organisational culture that support creativity and innovation may be enhanced through training and development. In particular McLean (2005) noted an example of a case where a lack of supervisory encouragement resulted in a lack of idea generation. He noted that this could be overcome through a training program targeting senior management focusing on developing behaviours necessary to support the team's work and ideas and then following this training with coaching support in key departments. Job rotation is only found to have a significant positive effect on organisational innovation. This may suggest that rotating individuals throughout departments within the business stimulates creativity to a lesser extent than utilising multi-disciplinary teams or brainstorming sessions. Authors such as Nahapiet and Ghoshal (1998) argue that knowledge sharing is a difficult task. Ghosh (2004) argues that knowledge sharing is prohibited by a number of human factors, including that knowledge sharing is time consuming; 
Table 4. Results of multivariate probit estimation of equation (1)

\begin{tabular}{|c|c|c|c|c|}
\hline & Product innovator & Process innovator & $\begin{array}{l}\text { Organisational } \\
\text { innovator }\end{array}$ & $\begin{array}{l}\text { Marketing } \\
\text { innovator }\end{array}$ \\
\hline \multirow[t]{2}{*}{ Constant } & $-2.2215^{\star \star \star}$ & $-1.5317^{\star \star \star}$ & $-1.5105^{\star \star \star}$ & $-1.8570 * \star \star$ \\
\hline & $(0.3806)$ & $(0.2868)$ & $(0.2878)$ & $(0.3065)$ \\
\hline \multicolumn{5}{|l|}{ R\&D } \\
\hline \multirow[t]{2}{*}{ Intramural R\&D } & $0.1448^{\star \star \star}$ & $0.0777^{\star \star \star}$ & $0.0481 * \star \star$ & $0.0565^{\star \star \star}$ \\
\hline & $(0.0094)$ & $(0.0088)$ & $(0.0090)$ & $(0.0086)$ \\
\hline \multirow[t]{2}{*}{ Extramural R\&D } & $0.0732^{* \star *}$ & $0.0360^{\star * *}$ & $0.0367^{* * *}$ & $0.0313^{\star \star *}$ \\
\hline & $(0.0143)$ & $(0.0128)$ & $(0.0134)$ & $(0.0121)$ \\
\hline \multicolumn{5}{|l|}{ Networking } \\
\hline \multirow[t]{2}{*}{ Backwards } & $0.2478^{\star \star \star}$ & $0.2047^{* * *}$ & $0.1767^{\star \star \star}$ & $0.1195^{\star \star \star}$ \\
\hline & $(0.0543)$ & $(0.0465)$ & $(0.0486)$ & $(0.0394)$ \\
\hline \multirow[t]{2}{*}{ Forwards } & $0.1701^{* * *}$ & $0.1398^{\star * *}$ & 0.0636 & 0.0599 \\
\hline & $(0.0633)$ & $(0.0600)$ & $(0.0617)$ & $(0.0511)$ \\
\hline \multirow[t]{2}{*}{ Horizontal } & 0.1012 & 0.0916 & 0.0168 & 0.0329 \\
\hline & $(0.1141)$ & $(0.1100)$ & $(0.1080)$ & $(0.0900)$ \\
\hline \multirow[t]{2}{*}{ Public } & -0.0428 & -0.0972 & 0.0735 & -0.0220 \\
\hline & $(0.0733)$ & $(0.0622)$ & $(0.0695)$ & $(0.0558)$ \\
\hline \multicolumn{5}{|l|}{ Firm specific factors } \\
\hline \multirow[t]{2}{*}{ Employment } & $0.0815^{\star \star \star}$ & $0.1169^{\star \star \star}$ & $0.0961^{\star \star \star}$ & $0.0662^{\star \star \star}$ \\
\hline & $(0.0270)$ & $(0.0249)$ & $(0.0253)$ & $(0.0243)$ \\
\hline \multirow[t]{2}{*}{ Irish owned } & 0.0243 & 0.0817 & 0.0019 & $0.2431^{\star \star *}$ \\
\hline & $(0.0659)$ & $(0.0608)$ & $(0.0602)$ & $(0.0607)$ \\
\hline \multicolumn{5}{|l|}{ Stimulating factors } \\
\hline \multirow[t]{2}{*}{ Work teams } & $0.3666^{\star \star \star}$ & $0.2529 * * *$ & $0.4375^{\star \star \star}$ & $0.3324^{\star \star \star}$ \\
\hline & $(0.0713)$ & $(0.0659)$ & $(0.0645)$ & $(0.0644)$ \\
\hline \multirow[t]{2}{*}{ Job rotation } & -0.0871 & 0.0549 & $0.2874^{\star \star \star}$ & 0.0458 \\
\hline & $(0.0733)$ & $(0.0667)$ & $(0.0656)$ & $(0.0642)$ \\
\hline \multirow[t]{2}{*}{ Brainstorming sessions } & $0.2363^{\star \star \star}$ & $0.2416^{\star \star \star}$ & $0.4269^{\star \star \star}$ & $0.4050^{\star \star \star}$ \\
\hline & $(0.0653)$ & $(0.0598)$ & $(0.0582)$ & $(0.0584)$ \\
\hline \multirow[t]{2}{*}{ Training } & 0.0955 & $0.2559 * \star \star$ & $0.2929 * \star \star$ & 0.0472 \\
\hline & $(0.0803)$ & $(0.0742)$ & $(0.0746)$ & $(0.0710)$ \\
\hline \multirow[t]{2}{*}{ Financial incentives } & -0.0346 & 0.0466 & 0.0554 & 0.1017 \\
\hline & $(0.1001)$ & $(0.0933)$ & $(0.0948)$ & $(0.0889)$ \\
\hline \multirow[t]{2}{*}{ Non-financial incentives } & 0.1022 & 0.1272 & 0.1422 & 0.1212 \\
\hline & $(0.0970)$ & $(0.0903)$ & $(0.0916)$ & $(0.0857)$ \\
\hline No. Obs & & & & 3,244 \\
\hline$\chi^{2}$ & & & & 1998.07 \\
\hline $\mathrm{P}>\chi^{2}$ & & & & 0.0000 \\
\hline Log-likelihood & & & & -6218.90 \\
\hline
\end{tabular}

Note

a: ${ }^{* *}, * *$ and $*$ indicate significance at the 99,95 and 90 percent level, respectively.

b: Base category is Sector B.

c: We control for NACE2 digit sectors in our estimation but to save space we do not present them in our table. 
Table 5. Results of multivariate probit estimation of equation (2)

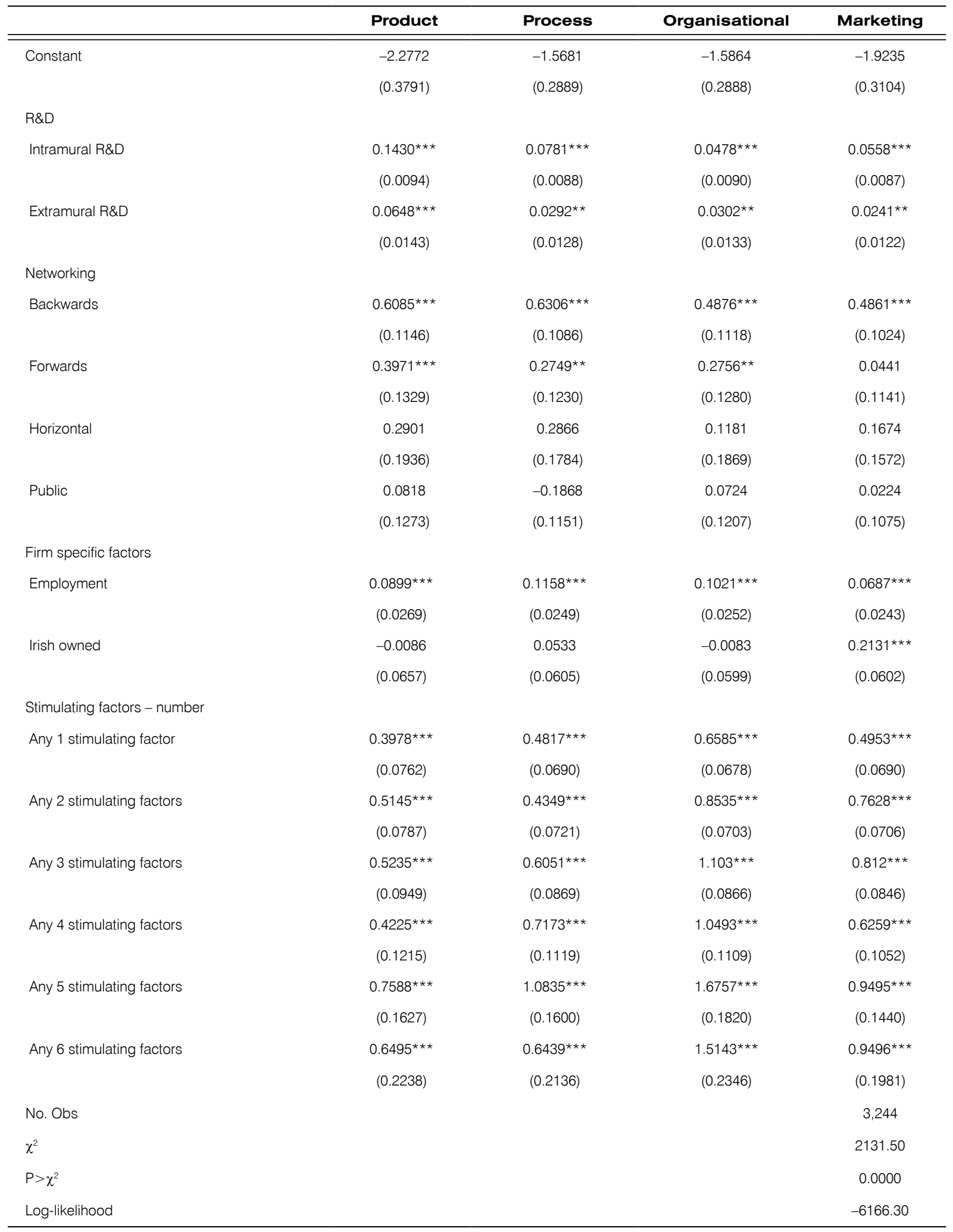

Note

a: ${ }^{\star \star \star},{ }^{\star *}$ and * indicate significance at the 99,95 and 90 percent level, respectively.

b: Base category is no encouragement variables.

c: We control for NACE2 digit sectors in our estimation but to save on space we do not present them in our table. 
knowledge is power which employees do not want to share, and knowledge sharing involves trust. In a world where an employee's salary, bonuses and promotion are linked to performance, it is difficult to encourage and promote knowledge sharing. Financial incentives and non-financial incentives have no impact on the likelihood of firms innovating. This may be a result of the limited use of these mechanisms by firms in our sample, or it may reflect the difficulties employers face when trying to motivate and incentivise their staff. As noted above while hedonically intrinsically motivated employees are more likely to be creative (Amabile, 1996), they are difficult to incentivise. Furthermore the use of incorrect incentives such as non-synergistic extrinsic motivators (such as money, promotion, or the threat of being fired) can demotivate them.

Turning to the other factors considered, these are consistent with what would be expected in an innovation production function. Both internal and extramural R\&D have a positive effect on all types of innovation considered. This is consistent with existing literature at an international level (Crépon et al., 1998; Love and Mansury, 2007; McCann and Simonen, 2005) and at an Irish level (Doran and O'Leary, 2011; Doran and Ryan, 2012; Roper et al., 2008). Likewise backward linkages are found to have a significant positive effect on all forms of innovation which again is consistent with studies such as Roper et al. (2008). However, forward linkages are only significant for product and process innovation and have no effect on the likelihood of organisational and marketing innovation. Horizontal linkages and public linkages are found to have no effect on the likelihood of any form of innovation. In an Irish context, this result is not unique (Doran and O'Leary, 2011). We also note that larger firms are more likely to introduce all forms of innovation while foreign and Irish owned firms are equally likely to introduce all forms of innovation with the exception of marketing innovation, where Irish firms are more likely to introduce this form of innovation. We control for broad NACE sectorial classifications in our estimation to control for sectorial differences in the likelihood of innovating (Pavitt, 1984).

\section{CONCLUSION}

This paper has analysed the effect of six different types of idea stimulating factors on the likelihood of four different types of innovation. A special module issued as part of the Irish CIS 2008-2010 provided data on the methods firms use to stimulate new ideas and/or creativity among their staff. Specifically six methods of stimulating innovation were identified by the Irish CIS. These are (i) brainstorming sessions; (ii) multidisciplinary or cross-functional work teams; (iii) job rotation of staff to different departments or other parts of their enterprise group; (iv) financial incentives for employees to develop new ideas; ( $v$ ) non-financial incentives for employees to develop new ideas, such as free time, public recognition, more interesting work, etc.; and (vi) training employees on how to develop new ideas or creativity.

After the estimation of a knowledge production function, evidence is found that brainstorming and multidisciplinary or cross-functional work teams are the most effective mechanism through which innovation can be stimulated. These two factors are found to increase the likelihood of all four types of innovation considered. Training employees on how to develop new ideas or creativity only has a significant impact on the likelihood of process and organisational innovation while job rotation only has a significant effect on organisational innovation. Financial and non-financial incentives are found to have no effect on any form of innovation considered in our analysis. Since creative people are more likely to be hedonically intrinsically motivated (i.e. self-starters who gain pleasure from completing the task) this result is not too surprising as this group is likely to negatively react to any extrinsic incentives which change the job into something they have to do rather than something they want to do.

The implications of our analysis for business are that innovation activity can be stimulated through the use of various techniques, with some having a specific effect on a sub-set of innovation types and others being applicable to a wide variety of innovations. Encouraging brainstorming and facilitating multidisciplinary or cross-functional work teams can have substantial innovation benefits while financial and non-financial incentives appear to have no significant role to play in the innovation process. We further note that the co-introduction of stimulus factors further increases the likelihood of firms innovating. However, as noted by Hansen and Birkinshaw (2007), the implementation of one of these measures is not sufficient in itself to ensure innovation. Time and consideration need to be taken in order to ensure that these measures are correctly implemented otherwise they may have counterproductive results. Future avenues for research into this area may be targeted at cross country or subsector studies to assess whether cultural factors or sector specific conditions may result in varying effectiveness of stimulation factors. However, this is beyond the data available to and the scope of this paper. 


\section{ENDNOTE}

We note at this point that we have also tested for complementarity across all forms of stimulating factors, however, no significant results were found for specific pairs.

\section{References}

Adams, K. (2006). 'The sources of innovation and creativity'. A Paper Commissioned by the National Center on Education and the Economy for the New Commission on the Skills of the American Workforce.

Alves, J., Marques, M., Saur, I. and Marques, P. (2007). 'Creativity and innovation through multidisciplinary and multisectoral cooperation'. Emerald Management Reviews, 16: 1, 27-34.

Amabile, T.M. (1988). 'A model of creativity and Innovation in organisations', in B. Staw and L. Cummings (eds), Research in Organisational Behaviour. Greenwich, CT: JAI Press, 123-167.

Amabile, T.M. (1996). Creativity and innovation in organizations, Boston, MA: Harvard Business School.

Amabile, T.M. (2013). Componential Theory of Creativity. Encyclopedia of Management Theory, Sage Publications.

Amabile, T.M. and Mueller, J.S. (2008). 'Studying creativity, its processes, and its antecedents', in Handbook of Organizational Creativity, NY: Lawrence Erlbaum Associates, 33-64.

Ames, C. (1992). 'Classrooms: Goals, structures, and student motivation'. Journal of Educational Psychology, 84: 3, 261-271.

Baer, M., Leenders, R.T.A., Oldham, G.R. and Vadera, A.K. (2010). 'Win or lose the battle for creativity: The power and perils of intergroup competition'. Academy of Management Journal, 53: 4, 827-845.

Beheshtifar, M. and Kamani-Fard, F.B. (2013). 'Organizational creativity: A substantial factor to growth'. International Journal of Academic Research in Business \& Social Sciences, 3: 3, 98104.

Boschma, R. (2005). 'Proximity and innovation: A critical assessment'. Regional Studies, 39: 1, 61-74.

Brynjolfsson, E. and Mendelson, H. (1997). 'Information systems and the organization of modern enterprise'. Massachusetts Institute of Technology, CCS Working Paper Series, 200.

Cappellari, L. and Jenkins, S. (2003). 'Multivariate probit regression using simulated maximum likelihood'. Stata Journal, 3: 3, 278-294.

Cappellari, L. and Jenkins, S. (2006). 'Calculation of multivariate normal probabilities by simulation, with applications to maximum simulated likelihood estimation'. Stata Journal, 6: 2, 156-189.

Cirella, S. and Shani, A.B. (2012). 'Collective creativity by design: Learning from an Italian fashion design company'. Irish Journal of Management, 32: 1, 5375.

Cohen, W. and Klepper, S. (1996). 'A reprise of size and R\&D'. Economic Journal, 106: 437, 925-951.

Cohen, W., Levin, R. and Mowery, D. (1987). 'Firm size and R\&D intensity: A re-examination'. The Journal of Industrial Economics, 35: 4, 543-565.

Çokpekin, Ö. and Knudsen, M.P. (2012). 'Does organizing for creativity really lead to ilnnovation?' Creativity and Innovation Management, 21: 3, 304-314.

Crépon, B., Duguest, E. and Mairesse, J. (1998). 'Research, innovation and productivity: An econometric analysis at the firm level'. Economics of Innovation and New Technology, 7: 2, 115-158.

CSO. (2010). Community Innovation Survey 2006-2008, Dublin: Stationery Office.

CSO. (2012). Community Innovation Survey 2008-2010, Dublin: Stationery Office.

Cummings, A. and Oldham, G. (1997). 'Enhancing creativity: Managing work for the high potential employee'. California Management Review, 40: 1, 22-38.

Deci, E. (1975). Instrinsic Motivation, NY: Plenum Publishing Co.

Deci, E. and Ryan, R. (1985). 'The general causality orientations scale: Self-determination in personality'. Journal of Research in Personality, 19: 2, 109-134.

DeDreu, C.K. (2002). 'Team innovation and team effectiveness: The importance of minority dissent and reflexivity'. European Journal of Work and Organizational Psychology, 11: 3, 285-298.

Dewhurst, M., Guthridge, M. and Mohr, E. (2009). 'Motivating people: Getting beyond money'. Mckinsey Quarterly, November, 145.

Doran, J., Jordan, D. and O'Leary, E. (2012a). 'The effects of national and international interaction on innovation: Evidence from the Irish CIS: 2004-6'. Industry and Innovation, 19: 5, 371-390.

Doran, J., Jordan, D. and O'Leary, E. (2012b). 'The effects of the frequency of spatially proximate and distant interaction on innovation by Irish SMEs'. 
Entrepreneurship and Regional Development, 24: 7-8, 705-727.

Doran, J., Jordan, D. and O'Leary, E. (2013). 'Effects of R\&D spending on innovation by Irish and foreign owned businesses'. Journal of the Statistical and Social Inquiry Society of Ireland, 42, 15-41.

Doran, J. and O'Leary, E. (2011). 'External interaction, innovation and productivity: An application of the innovation value chain for Ireland'. Spatial Economic Analysis, 6: 2, 199-222.

Doran, J. and Ryan, G. (2012). 'Regulation and firm perception, eco-innovation and firm performance'. European Journal of Innovation Management, 15: 4, 421-441.

Ettlie, J.E. and Reza, E.M. (1992). 'Organizational integration and process innovation'. Academy of Management Journal, 35: 4, 795-827.

Feldman, M. (1999). 'The new economics of innovation, spillovers and agglomeration: A review of empirical studies'. The Economics of Innovation and New Technology, 8: 1-2, 5-25.

Ford, C.M. (1996). 'A theory of individual creative action in multiple social domains'. Academy of Management Review, 21: 4, 1112-1142.

Freel, M. (2000). 'External linkages and product innovation in small manufacturing firms'. Entrepreneurship and Regional Development, 12: 3, 245-266.

Freel, M. (2003). 'Sectoral patterns of small firm innovation, networking and proximity'. Research Policy, 32: 5, 751-770.

Gardner, H. (1993). Creating Minds: An Anatomy of Creativity as Seen through the Lives of Freud, Einstein, Picasso, Stravinsky, Eliot, Graham, and Gandhi, NY: Basic Books.

Ghosh, T. (2004). 'Creating incentives for knowledge sharing'. Technical report, MIT Open Courseware. Sloan School of Management, Cambridge, Massachusetts, USA, 1-15.

Ghoshal, S. and Moran, P. (1996) 'Bad for Practice: A Critique of the Transaction Cost Theory'. Academy of Management Review, 21: 1, 13-47.

Girotra, K., Terwiesch, C. and Ulrich, K.T. (2010). 'Idea generation and the quality of the best idea'. Management Science, 56: 4, 591-605.

Hansen, M. and Birkinshaw, J. (2007). 'The innovation value chain'. Harvard Business Review, 85: 6, 121130

Heinze, T. (2013). 'Creative accomplishments in science: Definition, theoretical considerations, examples from science history, and bibliometric findings'. Scientometrics, 95: 3, 927-940.

Hossain, S. (2013). 'Creativity, social networking and changing business communication'. International Journal of Innovation and Applied Studies, 2: 4, 665-670.

Johansson, F. (2004). The Medici Effect: Breakthrough Insights at the Intersection of Ideas, Concepts, and Cultures, Boston, MA: Harvard Business Press.

Laffont, J.L. and Martimort, D. (2002). The Theory of Incentives: The Principal-Agent Model, Princeton, $\mathrm{NJ}$ : Princeton University Press

Lewis, T. and Wright, G.A. (2012). 'How does creativity complement today's currency of innovation?'. Journal of Strategic Innovation and Sustainability, 7: 3, 9-15.

Lindenberg, S. (2001). 'Intrinsic motivation in a new light'. Kyklos, 54: 2-3, 317-342.

Love, J. and Mansury, M. (2007). 'External linkages, R\&D and innovation performance in US business services'. Industry and Innovation, 14: 5, 477-496.

Madjar, N. and Ortiz-Walters, R. (2008). 'Customers as contributors and reliable evaluators of creativity in the service industry'. Journal of Organizational Behavior, 29: 7, 949-966.

Mansury, M. and Love, J. (2008). 'Innovation, productivity and growth in US business services: A firm level analysis'. Technovation, 28: 1-2, 52-62.

Martins, E. and Terblanche, F. (2003). 'Building organisational culture that stimulates creativity and innovation'. European Journal of Innovation Management, 6: 1, 64-74.

Mauzy, J., Harriman, R.A. and Harriman, R. (2003). Creativity, Inc: Building an Inventive Organization, Boston, MA: Harvard Business Press.

McCann, P. and Simonen, J. (2005). 'Innovation, knowledge spillovers and local labour markets'. Papers in Regional Science, 84: 3, 465-485.

McLean, L. (2005). 'Organizational culture's influence on creativity and innovation: A review of the literature and implications for human resource development'. Advances in Developing Human Resources, 7: 2, 226-246.

Mitchell, T.R. (1982). 'Motivation: New directions for theory, research, and practice'. Academy of Management Review, 7: 1, 80-88.

Mohrman, S.A., Cohen, S.G. and Mohrman, A.M. (1995). Designing Team-Based Organizations: New Forms for Knowledge Work, San Francisco, CA: Jossey-Bass.

Mumford, M.D. (2000). 'Managing creative people: Strategies and tactics for innovation'. Human Resource Management Review, 10: 3, 313-351.

Mumford, M.D. (ed) (2012). Handbook of Organizational Creativity, London: Elsevier.

Mumford, M.D. and Gustafson, S.B. (1988). 'Creativity 
syndrome: Integration, application, and innovation'. Psychological Bulletin, 103: 1, 27-43.

Mumford, M.D., Medeiros, K.E. and Partlow, P.J. (2012).

'Creative thinking: Processes, strategies, and knowledge'. The Journal of Creative Behavior, 46: 1, 30-47.

Nahapiet, J. and Ghoshal, S. (1998). 'Social capital, intellectual capital, and the organizational advantage'. Academy of Management Review, 23: 2, 242-266.

Nijstad, B.A. and De Dreu, C.K. (2002). 'Creativity and group innovation'. Applied Psychology, 51: 3, 400406.

Nyström, H. (1979). Creativity and Innovation, Chichester, UK: Wiley.

OECD. (2005). The Measurement of Scientific and Technological Activities Oslo Manual: Guidelines for Collecting and Interpreting Innovation Data, Luxembourg: OECD publishing.

Paulus, P. (2000). 'Groups, teams, and creativity: The creative potential of idea-generating groups'. Applied Psychology, 49: 2, 237-262.

Pavitt, K. (1984). 'Sectoral patterns of technical change: Towards a taxonomy and theory'. Research Policy, 13: 6, 343-374.

Puccio, G.J. and Cabra, J.F. (2010). 'Organizational Creativity', in J. Kaufman and R. Sternberg (eds), The Cambridge Handbook of Creativity. Cambridge, UK: Cambridge University Press.

Rank, J., Pace, V.L. and Frese, M. (2004). 'Three avenues for future research on creativity, innovation, and initiative'. Applied Psychology, 53: 4, 518-528.

Rietzschel, E., Nijstad, B. and Stroebe, W. (2006). 'Productivity is not enough: A comparison of interactive and nominal brainstorming groups on idea generation and selection'. Journal of Experimental Social Psychology, 42: 2, 244-251.

Roper, S. (2001). 'Innovation, networks and plant location: Some evidence for Ireland'. Regional Studies, 35: 3, 215-228.

Roper, S., Du, J. and Love, J. (2008). 'Modeling the innovation value chain'. Research Policy, 37: 6-7, 961-977.

Scott, S.G. and Bruce, R.A. (1994). 'Determinants of innovative behavior: A path model of individual innovation in the workplace'. Academy of
Management Journal, 37:3, 580-607.

Shalley, C.E., Zhou, J. and Oldham, G.R. (2004). 'The effects of personal and contextual characteristics on creativity: Where should we go from here?' Journal of Management, 30: 6, 933-958.

Shin, S.J. and Zhou, J. (2003). 'Transformational leadership, conservation, and creativity: Evidence from Korea'. Academy of Management Journal, 46: $6,703-714$

Simonton, D.K. (1980). 'Land battles, generals, and armies: Individual and situational determinants of victory and casualties'. Journal of Personality and Social Psychology, 38: 1, 110-119.

Storper, M. and Venables, A. (2004). 'Buzz: Face-toface contact and the urban economy'. Journal of Economic Geography, 4: 4, 351-370.

Sundstrom, E., De Meuse, K.P. and Futrell, D. (1990). 'Work teams'. American Psychologist, 45: 2, 120133.

Tidd, J. (2001). 'Innovation management in context: Environment, organization and performance'. International Journal of Management Reviews, 3: 3, 169-183.

Varis, M. and Littunen, H. (2010). 'Types of innovation, sources of information and performance in entrepreneurial Smes'. European Journal of Innovation Management, 13: 2, 128-154.

Wash, R. and MacKie-Mason, J.K. (2006), 'IncentiveCentered Design for Information Security'. Paper presented at USENIX Hot Topics in Security (HotSec 06), Vancouver, British Columbia, 31 July 2006

Weisberg, R. (1999). 'Creativity and Knowledge: A Challenge to Theories', in R. J. Sternberg (Ed.), Handbook of Creativity, Cambridge, UK: Cambridge University Press.

West, M. (2002). 'Sparkling fountains or stagnant ponds: An integrative model of creativity and innovation implementation in work groups'. Applied Psychology: An International Review, 51: 3, 355424.

Woodman, R.W., Sawyer, J.E. and Griffin, R.W. (1993). 'Toward a theory of organizational creativity'. Academy of Management Review, 18: 2, 293-321.

Zhou, J. and George, J.M. (2001). 'When job dissatisfaction leads to creativity: Encouraging the expression of voice'. Academy of Management Journal, 44: 4, 682-696. 


\section{Appendix 1}

\begin{tabular}{|c|c|c|}
\hline Variables & CIS question & Indicator type \\
\hline $\begin{array}{l}\text { Product } \\
\text { innovation }\end{array}$ & $\begin{array}{l}\text { During the three years } 2008 \text { to } 2010 \text {, did your enterprise introduce: (i) new or significantly improved } \\
\text { goods. (Exclude the simple resale of new goods purchased from other enterprises and changes of } \\
\text { a solely aesthetic nature); (ii) new or significantly improved services. }\end{array}$ & $1 / 0$ \\
\hline $\begin{array}{l}\text { Process } \\
\text { innovation }\end{array}$ & $\begin{array}{c}\text { During the three years } 2008 \text { to } 2010 \text {, did your enterprise introduce: (i) new or significantly improved } \\
\text { methods of manufacturing or producing goods or services; (ii) new or significantly improved } \\
\text { logistics, delivery or distribution methods for your inputs, goods or services; (iii) new or significantly } \\
\text { improved supporting activities for your processes, such as maintenance systems or operations for } \\
\text { purchasing, accounting or computing. }\end{array}$ & $1 / 0$ \\
\hline $\begin{array}{l}\text { Organisational } \\
\text { innovation }\end{array}$ & $\begin{array}{l}\text { During the three years } 2008 \text { to } 2010 \text {, did your enterprise introduce: (i) new business practices for } \\
\text { organising procedures; (ii) new methods of organising work responsibilities and decision-making; } \\
\text { (iii) new methods of organising external relations with other firms or public institutions. }\end{array}$ & $1 / 0$ \\
\hline $\begin{array}{l}\text { Marketing } \\
\text { innovation }\end{array}$ & $\begin{array}{c}\text { During the three years } 2008 \text { to } 2010 \text {, did your enterprise introduce: (i) new methods for product } \\
\text { placement or sales channels; (ii) new media or techniques for product promotion; (iii) significant } \\
\text { changes to the aesthetic design or packaging of a good or service (exclude changes that alter the } \\
\text { product's functional or user characteristics - these are product innovations); (iv) new methods of } \\
\text { pricing goods or services. }\end{array}$ & $1 / 0$ \\
\hline Creativity & $\begin{array}{l}\text { During the three years } 2008 \text { to } 2010 \text {, did your enterprise use any of the following methods to } \\
\text { stimulate new ideas or creativity among your staff? If yes, was the method successful in producing } \\
\text { new ideas or increasing creativity? (i) Brainstorming sessions; (ii) multidisciplinary or cross- } \\
\text { functional work teams; (iii) job rotation of staff to different departments or other parts of your } \\
\text { enterprise group; (iv) financial incentives for employees to develop new ideas; (v) non-financial } \\
\text { incentives for employees to develop new ideas, such as free time, public recognition, more } \\
\text { interesting work, etc.; (vi) training employees on how to develop new ideas or creativity. }\end{array}$ & $\begin{array}{c}\text { Series of six variables } \\
\text { with outcome } 1 / 0\end{array}$ \\
\hline Intramural R\&D & $\begin{array}{c}\text { Creative work undertaken within your enterprise to increase the stock of knowledge for developing } \\
\text { new and improved products and processes (include software development in-house that meets } \\
\text { this requirement). }\end{array}$ & $€$ per worker \\
\hline Extramural R\&D & $\begin{array}{c}\text { Same activities as above, but performed by other enterprises (including other enterprises or } \\
\text { subsidiaries within your group) or by public or private research organisations and purchased by } \\
\text { your enterprise. }\end{array}$ & $€$ per worker \\
\hline Networking & $\begin{array}{l}\text { During the three years } 2008 \text { to } 2010 \text {, did your enterprise co-operate on any of your innovation } \\
\text { activities with other enterprises or institutions? Innovation co-operation is active participation with } \\
\text { other enterprises or non-commercial institutions on innovation activities. Both partners do not need } \\
\text { to commercially benefit. Exclude pure contracting out of work with no active co-operation. }\end{array}$ & $\begin{array}{c}\text { Series of four variables } \\
\text { with outcome } \\
1 / 0 \text { indicating if } \\
\text { a firm engaged } \\
\text { with (i) customers, } \\
\text { (ii) suppliers, (iii) } \\
\text { competitors and } \\
\text { consultants, (iv) public } \\
\text { research institutions } \\
\text { and universities. }\end{array}$ \\
\hline
\end{tabular}

